\title{
Effect of Giving Brochures to Ventriculoperitoneal Shunted Children's Mothers About Preventing Shunt Infections
}

\author{
Ventriküloperitoneal Şantlı Çocukların Annelerini Şant Enfeksiyonlarını \\ Önleme Konusunda Bilgilendirmenin Etkisi
}

\author{
Seher Ünver'(iD), Banu Tütüncüler²(ID), Zeynep Kızılcık Özkan'(iD), Ümmü Yıldız Fındık'(ID) \\ ' Division of Surgical Nursing, Department of Nursing, Trakya University School of Health Sciences, Edirne, Turkey \\ 2 Department of Neurosurgery, Trakya University School of Medicine, Edirne, Turkey
}

Cite this article as: Ünver S, Tütüncüler B, Kızılcık Özkan Z, Yıldız Fındık Ü. Effect of giving brochures to ventriculoperitoneal shunted children's mothers about preventing shunt infections. J Pediatr Inf 2020;14(3):e97-e105.

* This study was presented as an oral presentation at the $15^{\text {th }}$ Neurosurgical Nursing Congress (11-14 April, 2019; Antalya-Turkey).

\begin{abstract}
Objective: The aim of this study was to evaluate and compare the effectiveness of giving oral information and printed informative brochures on information and application levels of mothers with VP shunted children to prevent infections.

Material and Methods: A prospective, randomized controlled trial design was conducted. Nine mothers in the study group were given printed informative brochures after a 15-minute oral informative session, whereas nine mothers in the control group were given only oral information. The effectiveness of these interventions was assessed at $15^{\text {th }}$ and $90^{\text {th }}$ days.

Results: Mothers in both groups achieved significantly higher information and application level scores at $15^{\text {th }}$ and $90^{\text {th }}$ days when compared to their initial evaluation $(p<0.05)$. In the study group, 90 days after the informative session, the mothers achieved statistically higher information level scores than the mothers in the control group $(U=8.000, p=0.019)$.

Conclusion: Giving printed informative brochures is more effective than giving only oral information on mothers' knowledge about preventing VP shunt infections. Printed informative brochures about preventing VP shunt infections could improve mothers' level of knowledge in the long term and avoid shunt infections.
\end{abstract}

Keywords: Hydrocephalus, infection, information, nurse, ventriculoperitoneal shunt
Öz

Giriş: Ventriküloperitoneal şantlar (VP) hidrosefalinin tedavisinde yaygın olarak kullanılmaktadır. VP şantlarının en sık görülen komplikasyonu enfeksiyon olup, cerrahi süreçteki koruyucu önlemlere rağmen ortaya çıkabilmektedir. Bu çalışmanın amacı, şant takılan çocukların annelerine şant enfeksiyonlarını önlemeye yönelik yapılan bilgilendirmenin annelerin bilgi ve uygulama düzeylerine etkisini belirlemektir.

Gereç ve Yöntemler: Prospektif, randomize kontrollü çalışma tasarımı kullanıldı. Çalışma grubundaki dokuz anneye 15 dakikalık sözel bilgilendirme oturumundan sonra bilgilendirme broşürü verildi, kontrol grubundaki dokuz anneye ise sadece sözel bilgilendirme yapıldı. Girişimlerin etkinliği 15. ve 90. günlerde değerlendirildi.

Bulgular: Her iki gruptaki annelerin bilgilendirme öncesindeki bilgi ve uygulama düzeylerinin 15. ve 90. günlerde istatistiksel olarak anlamlı derecede yükseldiği belirlendi $(p<0.05)$. Çalışma grubunun bilgilendirmeden 3 ay sonraki bilgi puan ortalamasının kontrol grubundan istatistiksel olarak anlamlı derecede yüksek olduğu belirlendi $(U=8.000, p=0.019)$.

Sonuç: Annelerin VP şant enfeksiyonlarını önleme konusundaki bilgilerinin arttırılması konusunda basılı bilgilendirme broşürlerinin verilmesi, sadece sözel bilgi vermekten daha etkilidir. VP şant enfeksiyonlarının önlenmesine yönelik bilgilendirme broşürleri, annelerin uzun vadede bilgi düzeylerini arttırabilir ve şant enfeksiyonlarını önleyebilir.

Anahtar Kelimeler: Hidrosefali, enfeksiyon, bilgilendirme, hemşire, ventriküloperitoneal şant

Correspondence Address/Yazışma Adresi

Seher Ünver

Trakya Üniversitesi Sağlık Bilimleri Fakültesi,

Hemşirelik Bölümü,

Cerrahi Hastalıkları Hemşireliği Anabilim Dalı,

Edirne-Türkiye

E-mail: seher.unver@hotmail.com 


\section{Introduction}

Hydrocephalus (HCP) occurs when there is imbalance between the production and absorbtion of the cerebrospinal fluid (CSF) so that excess CSF accumulates in the cerebral ventricles (1). According to the Hydrocephalus Association, the prevalence of hydrocephalus is $1 / 1000$ live births in the USA (2), and 0.3-2.5/1000 live births in Turkey $(3,4)$. Ventriculoperitoneal (VP) shunts are widely used in the treatment of HCP (5). VP shunts are composed of 3 parts: the ventricular catheter, pressure or flow controlled oneway valve, and peritoneal catheter. Thus, excess CSF is diverted from cerebral ventricules to the peritoneal cavity in a controlled unidirectional way; decreasing excess intracranial pressure $(6,7)$. HCP is mostly diagnosed in the pediatric group of patients. 1660 of 3000 VP shunt surgeries yearly performed to treat HCP in England are reported to be on pediatric patients (8). In Turkey, VP shunt surgery is performed on $88 \%$ of neonatal infants diagnosed with clinical HCP (9).

Infection is the most common complication of VP shunt surgery especially in the pediatric group of patients $(10,11)$. It results in prolonged periods of antibiotherapy and revision surgeries increasing hospital stay, infection related morbidities, and health expenditures $(12,13)$. VP shunt infections are reported to be seen in $10.5 \%$ of the infants and children (14). In a recent study by Tervonen et al. VP shunt related infection rate has been reported to be $12.5 \%$ (15). Telhan et al. have reported that $42.5 \%$ of pediatric patients with VP shunt infections are infants ( $<1$ year), and the rest are between the ages of 1-7 years (16).

Delay in recognition of VP shunt infections results in worse clinical outcome, prolonged hospital stay and increased health costs. Furthermore, long-term quality of life is affected in these patients due to permanent infection-related sequelae $(5,17,18)$. According to the Hydrocephalus Association, 2 million dollars are spent to treat HCP every year (2). Reinforcing aseptic/ hygienic preventive measures during peri-operative, early post-operative, and long-term daily care are important in preventing VP shunt related infections (19). However, infections are common regardless of strict peri-operative preventive measures (20). Thus, post surgery in-hospital and long-term care are important in preventing shunt related surgery as well.

Hand hygiene, using aseptic techniques in surgical wound care, antibiotic prophylaxis, nursing, and education about taking care of children with VP shunts are reported to be paramount in preventing infections in literature (21). According to the 2017 evidence-based recommendations by the World Health Organization (22), maintaining hand hygiene is strongly suggested to prevent infections. Educating parents and caretakers, preparing informative brochures and posters are recommended to prevent VP shunt infections (23). In a study involving parents of children with VP shunts, the percentage of VP shunt revision surgery is reported to be statistically less in children with parents educated about care of VP shunt related symptoms and complications (13). Nevertheless, in a study on the parents of children with VP shunts experience, it is reported that $80 \%$ of the parents are not informed about potential VP shunt complications and $50.7 \%$ of parents lack information about appropriate shunt care (24).

Nurses play an important role in the early postoperative care of VP shunt patients (25). They share significant responsibility for surgical wound care and recognizing VP shunt related complications. In addition, they are responsible for maintaining effective health-care environment and inform and educate the parents of these patients about appropriate daily care (26). Regarding the long-term care of children with VP shunts, nurses play important roles in educating the parents and increasing the quality of life (27). In Turkey, the caregivers of children are almost always mothers, especially when the child bears a health problem. Mothers recognizing the early symptoms of infections and VP shunt related complications are of paramount importance in pediatric VP shunt patients as it affects the long-term well being of the child as well as avoidable revision surgeries, long hospital stays, and increased health costs (6).

Providing written and oral information for patients and caregivers is a standardized procedure in developed countries and it is recommended to establish healthcare educations to families of children to maintain development on their needs (28). However, in underdeveloped or developing countries, educating the caregiver of a chronic patient is either totally overlooked or substandard in most institutions. As authors, we would like to emphasize that families of the children with VP shunts should be educated on surgical wound care, skin care, and signs and symptoms of infection. Furthermore, we aimed to compare the effectiveness of supplying mothers with written education material versus only oral education on recognizing and avoiding VP shunt infections.

\section{Purpose and Hypotheses}

The purpose of this study was to evaluate and compare the effectiveness of giving oral information and printed informative brochures on information and application level of mothers to prevent VP shunt infections.

Hypothesis 1: Information level of the mothers in the study group will be higher than the control group at 90 days after giving oral information and informative brochure.

Hypothesis 2: Application of the learned information will be higher in the study group than the control group at 90 days after giving oral information and informative brochure.

\section{Materials and Methods}

\section{Study Design and Sample}

This study is a prospective, randomized controlled trial, conducted between $5^{\text {th }}$ May 2016-3 ${ }^{\text {rd }}$ March 2018 by voluntary participation of mothers of children treated in neurosurgery department of a university hospital. 
We determined the number of the study and control groups according to the number of patients hospitalized in the neurosurgery department in the previous year. Between $1^{\text {st }}$ January 2015 and 31 ${ }^{\text {st }}$ December 2015, 1015 patients, six of which were pediatric VP shunt patients (between 0-15 years of age), were hospitalized by neurosurgery department. The percentage of pediatric HCP patients ungergoing VP shunt surgery were $0.6 \%$. Using power analysis yielding $95 \%$ confidence interval, $5 \%$ margin of error and $85 \%$ statistical power, we included nine mothers for the study group, and nine mothers for the control group, totaling 18 mothers.

The study was conducted in a reference hospital, where referred patients from whole Thrace region of Turkey are hospitalized and treated. In the neurosurgical department, both pediatric and adult patients are hospitalized. Pediatric patients are hospitalized in single rooms.

We included voluntary mothers who are the sole caregiver of the pediatric patients (0-15 years of age) undergoing first time or revision VP shunt surgeries, and who speak Turkish as their native language, and who are literate in Turkish. The mothers satisfying the inclusion criteria were randomized to study and control groups.

Randomization was performed by researcher (ZKÖ) as follows: In-patient protocol numbers of the patients were written down and a consecutive number starting with one (1) was assigned for each protocole number. The odd protocole numbers assigned were included in the study group, and the even protocole numbers assigned were included in the control group.

\section{Blindedness of the Study}

The study is not a blinded study.

\section{Study Protocol and Data Collection}

In the study, "identification form", "questionnaire on information about preventive measures regarding VP shunt infections", and "questionnaire on application of preventive measures regarding VP shunt infections" were used to collect research data. These questionnaires were prepared by the authors according to the literature review, and the content validation of them was accomplished by consulting three neurosurgery specialists and two specialist nurses.

"Identification form" is composed of 10 questions about descriptive information on the mother and the patient such as ages of the mother and the patient, sex of the patient, previous education on VP shunt related infections, and the number of VP shunt surgeries the patient underwent.

"Questionnaire on information about preventive measures regarding VP shunt infections" aimed to determine the information level of preventive measures by the mothers before and after they were informed about VP shunt related infection prevention measures. The questionnaire consists of a total of 25 phrases. Sixteen of the 25 phrases are affirmative sentences such as "The cleanliness of the child's clothes prevents the development of infections", "Healthy and balanced nutrition of the child helps to prevent infections", and nine of them are negative sentences, such as "Being in a crowded, polluted environment does not pose a risk of infection for child", "Tooth decays do not cause infections". The mothers are asked to check the phrases as "correct" or "false". Every correct answer was scored as "1" point so that the highest score obtainable was " 25 " and the lowest score was " 0 ". The higher the scores the better informed the mothers were about VP shunt related problems (Figure 2).

"Questionnaire on application of preventive measures regarding VP shunt infections" aimed to determine the application level of preventive measures by the mothers before and after they were informed about VP shunt related infection prevention measures. The questionnaire consists of 20 affirmative phrases on application of shunt infection prevention measures such as"I keep away my child from people who have influenza and flu", "I consult a physician immediately in case of any infection with fever (throat infection, urinary tract infection, etc.)" etc. The phrases were selected from the informative questionnaire and included accurate information about what the mothers should do to prevent infection. The mothers were asked to check the phrases as "correct" or "false". The correct answers were scored as " 1 " point and the wrong anwers were scored as " 0 " so that the highest possible score was " 20 " and the lowest was " 0 ". The higher the scores the more accurate the mothers applied the preventive measures (Figure 2).

An "informative brochure" on preventing VP shunt infections was prepared by the authors in the light of the literature and specialist opinions. The brochure included information about diagnosis and the clinical signs of HCP, the description of the VP shunt system, signs and symptoms of shunt infection and infection prevention measures such as hand and body hygiene, clean clothes, oral hygiene, tooth-care, measuring body temperature, seeking early medical care for common infections such as upper respiratory tract infections or urinary tract infections.

Both oral and written consents were obtained from all the mothers. The mothers were initially interviewed by the researcher (ZKÖ) while their children were hospitalized, and the "identification form", the "questionnaire on information about preventive measures regarding VP shunt infections" and the "questionnaire on application of preventive measures regarding VP shunt infections" were completed to get baseline information and assess the mothers' baseline information, and application level. As the follow up interviews were planned to be conducted on the phone, the forms and the questionnaires 


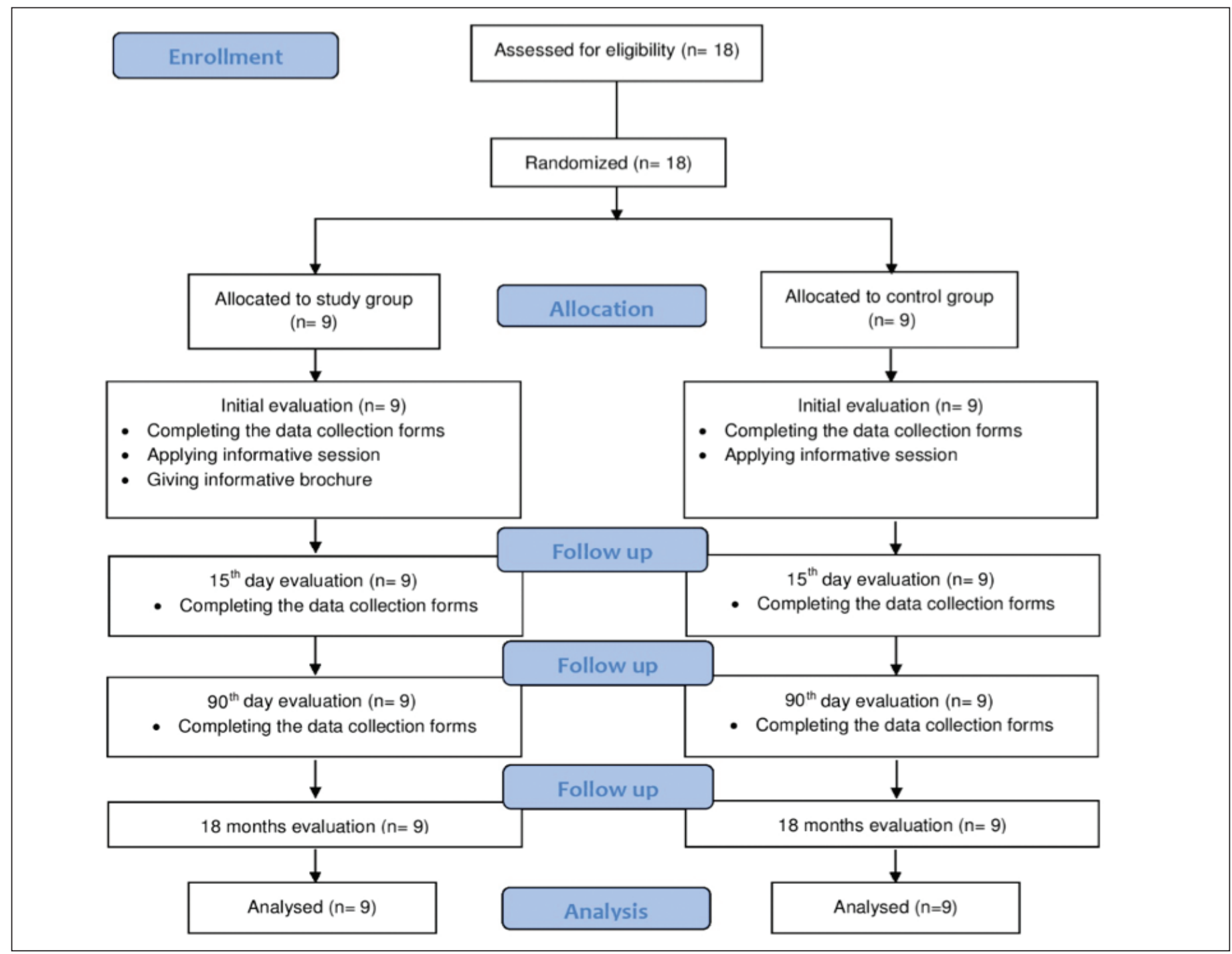

Figure 1. The CONSORT flow diagram.

were read aloud to the mother, and the answers were filled in by the researchers to ensure that the mothers understand the phrases. During their hospital stay, a 15-minute informative session about VP shunt infections and preventive measures was carried out with mothers by the researcher (SÜ). The mothers were allowed to ask questions, and their questions were answered. After the session, the "informative brochure" prepared by the authors were given to mothers in the study group as printed education material. No "informative brochure" was given to the control group.

Fifteen days and 90 days after the 15-minute informative session, mothers both in the study and control group were interviewed on the phone by researcher (SÜ) to assess the effectiveness of the informative session and the brochure. Mothers completed the "questionnaire on information about preventive measures regarding VP shunt infections" and the "questionnaire on application of preventive measures regarding VP shunt infections" on the phone during both of the follow up interviews. The CONSORT flow diagram of this study is presented on Figure 1.

\section{Ethical Considerations}

The study was approved by the university research ethics committee (approval number: 06/02 on 30.03.2016), and the hospital directory (approval number: 79056779-600 on 05.04.2016). The volunteering paticipants gave oral and written consent. The participants were informed that the information they revealed would only be used for research purposes, and that their privacy would be maintained. The study was carried out in accord with Helsinki Declaration, National Good Clinical Practices Guideline and Research Ethics Committee Regulations. 


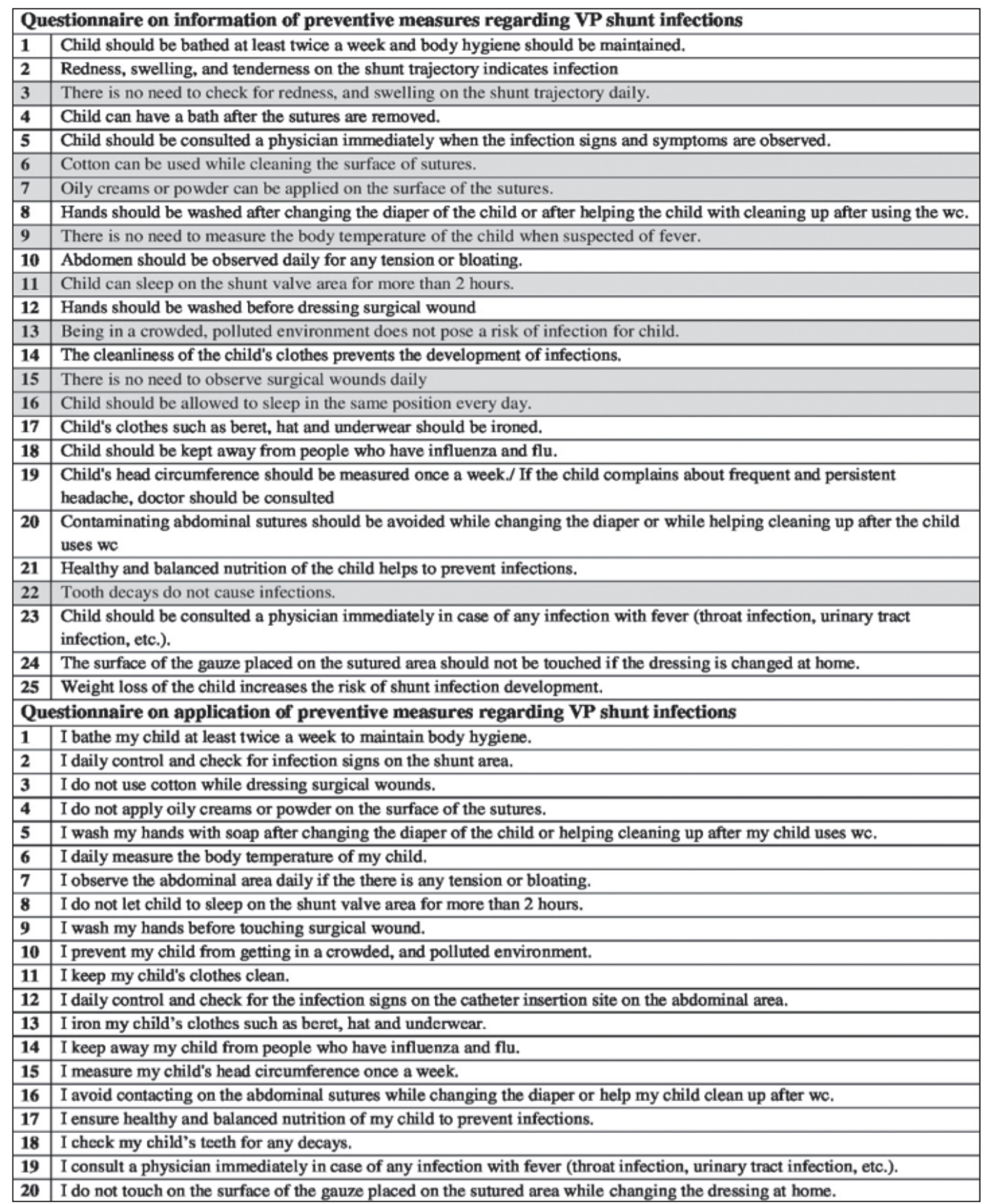

Figure 2. Questionnaires on information and application of preventive measures regarding VP shunt infections. Note: The grey lines show the negative sentences.

\section{Data Analysis}

Data were analyzed in terms of percentage, arithmetical mean, and standard deviation. Kolmogorov-Smirnov normality test is applied to confirm normal distribution of patient data. Data were statistically analyzed using chi-square, paired samples t-test, and Mann Whitney-U test on SPSS (Statistical Package for Social Sciences for Windows, Version 20.0). Statistical significance was set at $\mathrm{p}<0.05$.

To analyze the content validity of the questionnaires, the Content Validation Index (CVI) was calculated based on the relevance score of the expert responses using a four-likert rating scale (not relevant $=1$, somewhat relevant $=2$, quite relevant $=3$, very relevant $=4$ ). The CVI for each item was found as +1.00 as having acceptable relevancy (for five experts expected $\mathrm{CVI}>0.99$ ).

The G-Power (G Power 3.1 9.2, Kiel, Germany) program was used for post-hoc power analysis to determine if the sample size is enough to detect significant effects. The statistical power was calculated as 0.47 (effect size $d=0.8$, a err prob $=0.05$, sample size $=18$ ). 
Ünver et al.

Table 1. Descriptive information on VP shunted children and their mother $(n=18)$

\begin{tabular}{|c|c|c|c|}
\hline Descriptive Features & $\begin{array}{l}\text { Study group } \\
\text { (mean } \pm \text { SD) }\end{array}$ & $\begin{array}{l}\text { Control group } \\
\text { (mean } \pm \text { SD) }\end{array}$ & Statistical values \\
\hline Age of the mother (years) & $31.33 \pm 7.33$ & $32.88 \pm 6.62$ & $t=-0.472$ \\
\hline Age of the child (months) & $52.22 \pm 47.36$ & $63.55 \pm 73.89$ & $\begin{array}{l}p=0.643^{*} \\
t=-0.387 \\
p=0.704^{*}\end{array}$ \\
\hline \multirow[t]{2}{*}{ Number of shunt surgeries } & $1.55 \pm 0.72$ & $2.00 \pm 0.86$ & $\begin{array}{l}\mathrm{t}=-1.180 \\
\mathrm{p}=0.255^{*}\end{array}$ \\
\hline & n (\%) & n (\%) & \\
\hline $\begin{array}{c}\text { Education of the mother } \\
\text { Elementary school }\end{array}$ & $9(100)$ & $9(100)$ & - \\
\hline $\begin{array}{l}\text { Previous education of the } m \\
\text { on VP shunt related infectio } \\
\text { Yes } \\
\text { No }\end{array}$ & $\begin{array}{c}0(0) \\
9(100)\end{array}$ & $\begin{array}{c}0(0) \\
9(100)\end{array}$ & - \\
\hline $\begin{array}{l}\text { Sex of the child } \\
\text { Female } \\
\text { Male }\end{array}$ & $\begin{array}{l}2(22.2) \\
7(77.8)\end{array}$ & $\begin{array}{l}3(33.3) \\
6(66.7)\end{array}$ & $p=0.500^{* *}$ \\
\hline $\begin{array}{l}\text { Time of birth } \\
\text { Term } \\
\text { Preterm }\end{array}$ & $\begin{array}{l}8(88.9) \\
1(11.1)\end{array}$ & $\begin{array}{l}7(77.8) \\
2(22.2)\end{array}$ & $p=0.500^{* *}$ \\
\hline
\end{tabular}

\section{Results}

Mean age of the mothers participated in the study group was $31.33 \pm 7.33$ years, and mean age of the children with VP shunts were $57.88 \pm 60.49$ months. All mothers had graduated from elementary school. None of them had been previously educated about VP shunt related complications. There were no significant differences in VP shunted children's and their mother's demographic features between the study and the control group. Detailed information about the demographic features of mothers and children is presented in Table 1.

Information level of the mothers was evaluated based on the scores the mothers achieved on the "questionnaire on information about preventive measures regarding VP shunt infections".

There was no statistical difference in the initial scores the mothers achieved in the study group and the control group $(U=27.500, p=0.246)$. Mothers both in the study and control group achieved significantly higher scores 15 and 90 days after informative session when compared to their initial evaluation. When we compared the difference between the study and the control group 15 days after the informative session, there was no statistical significance $(U=20.500, p=0.063)$. However, 90 days after the informative session the mothers in the study group performed statistically higher scores than the mothers in the control group $(U=8.000, p=0.019)$ (Table 2). Hypothesis 1 was supported.
The mothers' application levels of preventive measures on VP shunt infections was evaluated based on the scores on the "questionnaire on application of preventive measures regarding VP shunt infections".

Fifteen days and 90 days after the informative session both the control and the study group achieved higher scores than the initial evaluation $(p<0.05)$ (Table 2$)$. There was no statistical difference in the initial scores the mothers achieved in the study group and the control group $(U=35.000, p=0.622)$. Furthermore, there was no statistical difference between the groups both 15 days and 90 days after the informative session $(U=37.000, p=0.750 ; U=30.000, p=0.320$, respectively) (Table 2). Hypothesis 2 was not supported.

\section{Discussion}

$\mathrm{HCP}$ in pediatric patients is a relatively common entity in pediatric neurosurgery practice. The treatment and long-term management of HCP patients are economically exhaustive and clinically labor-demanding because of the high frequency of complications both in short and long term. Although endoscopic techniques are becoming increasingly popular, it has not completely replaced the use of VP shunt placement. VP shunt insertion surgery is still widely used in HCP treatment. In spite of the progress in the VP shunt system technology (antibiotic coated shunts, etc), VP shunt related infections remain to be the most frequent complication in pediatric patients. 
Table 2. Distribution of the scores mothers achieved on information and application questionnaires $(n=18)$

\begin{tabular}{|c|c|c|c|c|c|}
\hline & Groups & $\begin{array}{c}\text { Initial } \\
\text { evaluation }\end{array}$ & $15^{\text {th }}$ day evaluation & $90^{\text {th }}$ day evaluation & Statistical values* \\
\hline \multirow[t]{2}{*}{ Information score } & Study & $19.77 \pm 3.38$ & $24.33 \pm 1.11$ & $24.44 \pm 1.01$ & $\begin{array}{c}\mathrm{p} 0-1=0.006 \\
\mathrm{t}=-3.682 \\
\mathrm{p} 0-2=0.006 \\
\mathrm{t}=-3.677 \\
\mathrm{p} 1-2=0.347 \\
\mathrm{t}=-1.000\end{array}$ \\
\hline & Control & $18.22 \pm 2.63$ & $23.00 \pm 1.73$ & $23.00 \pm 1.50$ & $\begin{array}{c}\mathrm{p} 0-1=0.001 \\
\mathrm{t}=-4.793 \\
\mathrm{p} 0-2=0.001 \\
\mathrm{t}=-4.932 \\
\mathrm{p} 1-2=1.000 \\
\mathrm{t}=0.000\end{array}$ \\
\hline Statistical values** & & $\begin{array}{c}p=0.246 \\
U=27.500\end{array}$ & $\begin{array}{c}p=0.063 \\
U=20.500\end{array}$ & $\begin{array}{l}\mathrm{p}=0.019 \\
\mathrm{U}=8.000\end{array}$ & \\
\hline \multirow[t]{2}{*}{ Application score } & Study & $14.44 \pm 3.50$ & $18.55 \pm 1.01$ & $17.66 \pm 2.69$ & $\begin{array}{c}\mathrm{p} 0-1=0.003 \\
\mathrm{t}=-4.203 \\
\mathrm{p} 0-2=0.002 \\
\mathrm{t}=-4.566 \\
\mathrm{p} 1-2=0.500 \\
\mathrm{t}=-0.707\end{array}$ \\
\hline & Control & $13.11 \pm 3.14$ & $17.66 \pm 2.69$ & $17.66 \pm 2.69$ & $\begin{array}{c}\mathrm{p} 0-1=0.002 \\
\mathrm{t}=-4.428 \\
\mathrm{p} 0-2=0.002 \\
\mathrm{t}=-4.428\end{array}$ \\
\hline Statistical values** & & $\begin{array}{l}p=0.622 \\
U=35.000\end{array}$ & $\begin{array}{l}p=0.750 \\
U=37.000\end{array}$ & $\begin{array}{l}p=0.320 \\
U=30.000\end{array}$ & \\
\hline
\end{tabular}

In this study, although a small sample of mothers was included, we uncovered the fact that revision surgery patient or not, none of the mothers was previously informed about VP shunt infections. This is a valuable observation for professionals dealing with pediatric VP shunt surgery in developing countries. We believe that this calls attention to improve parent education in healthcare institutes at least, but not the least in Thrace region of Turkey.

Mothers were willing to get information about their children's health problem. Hence, both the study and the control group achieved significantly higher scores after a 15-minute informative session. Furthermore, giving the mothers informative brochures significantly increased the level of information in the study group at $90^{\text {th }}$ day evaluation. We were happy to observe the instances that mothers kept the brochures we gave in their purses, at their child's bedside, etc., and that mothers acknowledged referring to the brochure frequently to give their child best care. We believe that giving mothers printed education materials keep the mothers' interest of getting further information about their children's health conditions, and serve as a brief guidence reference $(7,13,29)$. Therefore, it is a cheap and effective means of preventing avoidable causes of VP shunt infections, and early recognition of infections by parents (29).

In our study, 15-minute oral informative session alone significantly increased the evaluation scores of the mothers' application skills of preventive measures regarding VP shunt infections both in the study and the control group. There was no statistical difference in applying the given information levels of mothers between the study and the control group on $15^{\text {th }}$ and $90^{\text {th }}$ days of evaluation. The mothers included in the study had elementary formal education and no previous guidance about VP shunt complications and their preventive measures. We assumed that although single brief informative session was effective in increasing their awareness of infection prevention measures, it takes time and repeated education to transform given information to practice. There are reports supporting the view that printed education materials boost the caregivers' awareness of infection prevention measures $(30,31)$. They also support the coping mechanism of families having children with chronic care needs (26). In a review on day care of VP shunted children, informative internet sites recommended by physicians were also reported to be effective in educating parents about recognizing and avoiding VP shunt related problems (32). 
Ünver et al.

In our study, we observed that none of the 18 mothers included in the study were previously informed about infection recognition and prevention measures. Oral informative sessions significantly increased the level of information about preventing VP shunt infections and their behavior patterns in the short (15 days) and the long term (90 days) both in the study and the control group of mothers. Giving the mothers informative brochure handouts significantly increased the mothers' level of information in the long term. We concluded that giving mothers printed informative brochures keeps their interest and their motivation of learning about their children's health conditions alive.

In conclusion, oral information and/or printed informative brochures on preventing VP shunts are effective in educating mothers of VP shunted children, and printed informative brochures may be more effective in changing mothers' child care practices on avoiding infections.

\section{Study Limitations}

There are some limitations in the study. First of all, the number of the study and the control group samples are low. Secondly, although the study is randomized and controlled, it is not blinded. Thirdly, all the caregivers of the VP shunted children were their mothers, so the results of this study cannot be generalized to children with fathers or state employed caregivers as their primary caregiver.

\section{Conclusion}

We strongly suggest surgical nurses and other healthcare professionals at neurosurgery departments give the mothers of VP shunted children printed informative brochures on their discharge from the hospital, and organize informative sessions at regular intervals to improve the mothers' level of information, and their ability to apply them in daily practice to prevent avoidable causes of VP shunt infections.

\section{Acknowledgements}

This study is financially supported by TUBAP Committee (Project Number: 2016/207). We thank to TUBAP for funding this project and the mothers for participating in this study.

Ethics Committe Approval: The ethical approval for this study was obtained from the Ethics Committee of Trakya University Medical Faculty (Decision number: 06/02, Date: 30.03.2016)

Informed Consent: The verbal and written informed consent was taken from the children's mothers.

Peer-review: Externally peer-reviewed.

Author Contributions: Concept - SÜ, BT, ZKÖ, ÜYF; Design - SÜ, BT, ZKÖ, ÜYF; Data Collection and/or Processing - SÜ, BT, ZKÖ; Analysis and/or Interpretation - SÜ, ZKÖ; Literature Search - SÜ, BT, ZKÖ, Writing - SÜ, BT, ZKÖ, ÜYF; Critical Review - All of authors.

Conflict of Interest: No conflict of interest was declared by the authors.
Financial Disclosure: The authors declared that this study has received no financial support.

\section{References}

1. Rekate HL. A contemporary definition and classification of hydrocephalus. Semin Pediatr Neurol 2009;16:9-15. [CrossRef]

2. Facts about hydrocephalus. Hydrocephalus Association. https://www. hydroassoc.org/about-us/newsroom/facts-and-stats-2/ (Assessed 22 June 2018). [CrossRef]

3. Baș NS. Epidemiology of hydrocephalus: incidence and prevalence. Turkiye Klinikleri J Neurosurg-Special Topics 2015;5:7-9. [CrossRef]

4. Duru S. Intrauterine hydrocephalus treatment. Turkiye Klinikleri J Neurosurg-Special Topics 2015;5:87-91. [CrossRef]

5. Reddy KG, Bollam P, Caldito G. Ventriculoperitoneal shunt surgery and the risk of shunt infection in patients with hydrocephalus: long-term single institution experience. World Neurosurg 2012;78:155-63. [CrossRef]

6. Joseph R, Killian M, Brady E. Nursing care of infants with a ventriculoperitoneal shunt. Adv Neonat Care 2017;17:430-9. [CrossRef]

7. Elaziz MSA, Elaal EMA, El-Sadik BRA, Said KM. Nursing management protocol for mothers of children having ventricular peritoneal shunt. Egypt Nurs J 2017;14:226-34. [CrossRef]

8. Pickard J, Richards $H$, Seeley $H$, Mendez RF, Joannides A. Draft Report 2017. UK Shunt Registry. https://brainhtc.org/wp-content/uploads/2017/10/UKSRDraftReport2017FINAL.pdf (Assessed 22 June 2018). [CrossRef]

9. Özdemir H, Bilgen H, Özek E, Akman I, Özek M. Intraventricular reservoir application in neonates with progressive hydrocephalus. Turk Pediatr Arch 2013;48:200-3. [CrossRef]

10. Yakut N, Soysal A, Kepenekli KE, Dalgic N, Yilmaz Ciftdogan D, Karaaslan $A$, et al. Ventriculoperitoneal shunt infections and re-infections in children: a multicentre retrospective study. Br J Neurosurg 2018;32:196-200. [CrossRef]

11. Erps A, Roth J, Constantini S, Lerner-Geva L, Grisaru-Soen G. Risk factors and epidemiology of pediatric ventriculoperitoneal shunt infection. Pediatr Int 2018;60:1056-61. [CrossRef]

12. Riva-Cambrin J, Kestle JR, Holubkov R, Butler J, Kulkarni AV, Drake J, et al. Risk factors for shunt malfunction in pediatric hydrocephalus: a multicenter prospective cohort study. J Neurosurg Pediatr 2016;17:382-90. [CrossRef]

13. Ackerman LL, Fulkerson DH, Jea A, Smith JL. Parent/guardian knowledge regarding implanted shunt type, setting, and symptoms of malfunction/infection. J Neurosurg Pediatr 2018;21:359-66. [CrossRef]

14. Lee JK, Seok JY, Lee JH, Choi EH, Phi JH, Kim SK, et al. Incidence and risk factors of ventriculoperitoneal shunt infections in children: a study of 333 consecutive shunts in 6 years. J Korean Med Sci 2012;27:1563-8. [CrossRef]

15. Tervonen J, Leinonen V, Jaaskelainen JE, Koponen S, Huttunen TJ. Rate and risk factors for shunt revision in pediatric patients with hydrocephalus-a population-based study. World Neurosurg 2017;101:615-22. [CrossRef]

16. Telhan L, Çavuşoğlu F, Türkmenoğlu O, Çetinkaya F. Etiologic and prognostic assessment of children with ventriculoperitoneal shunt infections. J Pediatr Inf 2010;4:100-3. [CrossRef]

17. Chen J, Wang Y, Yang L, Zhang C, Chen W, He J, et al. Infections of ventriculoperitoneal shunt and a simple effective treatment. Int J Clin Exp Med 2016;9:4557-62. [CrossRef]

18. Prakash P, Dhandapani M, Ghai S, Singh NV, Dhandapani S. Quality of life among children who had undergone ventriculoperitoneal shunt surgery. J Pediatr Neurosci 2018;13:189-94. [CrossRef] 
19. Agarwal N, Shukla RM, Agarwal D, Gupta K, Luthra R, Gupta J, et al. Pediatric ventriculoperitoneal shunts and their complications: an analysis. J Indian Assoc Pediatr Surg 2017;22:155-7. [CrossRef]

20. Gayretli Aydın ZG, Aydemir D, Acar Arslan E, Özkaya E, Kamaşak T, Şahin $S$, et al. Evaluation of ventriculoperitoneal shunt infections in children. J Pediatr Inf 2018;12:147-52. [CrossRef]

21. Xu H, Hu F, Hu H, Sun W, Jiao W, Li R, et al. Antibiotic prophylaxis for shunt surgery of children: a systematic review. Childs Nerv Syst 2016;32:253-8. [CrossRef]

22. Storr J, Twyman A, Zingg W, Damani N, Kilpatrick C, Reilly J, et al. Core components for effective infection prevention and control programmes: new WHO evidence-based recommendations. Antimicrob Resist Infect Control 2017;6:1-18. [CrossRef]

23. Chandonnet CJ, Boutwell KM, Spigel N, Carter J, DeGrazia M, Ozonoff $A$, et al. It's in your hands: an educational initiative to improve parent/ family hand hygiene compliance. Dimens Crit Care Nurs 2017;36:32733. [CrossRef]

24. Erbaş $A$, Bulut $H$. The experienced problems of families having children with cerebrospinal fluid shunt. Gazi Uni Health Sci J 2017;2:9-19. [CrossRef]

25. Tavares PAJ, Filho PTH, Ferreira AS, Avila MAG. Construction and validation of educational material for children with hydrocephalus and their informal caregivers. World Neurosurg 2018;114:381-90. [CrossRef]
26. Athanasakis E, Ermidou D. Post-operative complications of ventriculoperitoneal shunt in hydrocephalic pediatric patients-nursing care. Int J Caring Sci 2011;4:66-71. [CrossRef]

27. Neves ET, Cabral IE. Caring of children with special health care needs: challenges to families and pediatric nursing. Rev Eletr Enf 2009;11:52738. [CrossRef]

28. Choi EK, Ji Y, Bae E, Jang M. Parents' needs concerning their children with spina bifida in South Korea: A mixed method study. J Pediatr Nurs 2019;47:36-44. [CrossRef]

29. De Rouck S, Leys M. IIIness trajectory and Internet as a health information and communication channel used by parents of infants admitted to a neonatal intensive care unit. J Adv Nurs 2013;69:1489-99. [CrossRef]

30. Khalafallah DH, Ahmed EM, Mohamed FR, Ali KB, Mohamed SA. The impact of protocol of care for mothers of children with ventriculoperitoneal shunt on occurrence of postoperative complications. Int J Res Appl Nat Soc Sci 2017;5:73-83. [CrossRef]

31. Landier M, Villemagne T, Le Touze A, Braik K, Meignan P, Cook AR, et al. The position of a written document in preoperative information for pediatric surgery: aA randomized controlled trial on parental anxiety, knowledge, and satisfaction. J Pediatr Surg 2018;53:375-80. [CrossRef]

32. Naftel RB, Safiano NA, Falola MI, Shannon CN, Wellons JC, Johnston JM. Technology preferences among caregivers of children with hydrocephalus. J Neurosurg Pediatr 2013;11:26-6. [CrossRef] 